\title{
EGG QUALITY AND HATCHABILITY OF In situ - REARED KEDU AND CEMANI HENS FED DIET OF FARMER FORMULATION SUPPLEMENTED WITH VITAMIN E
}

\author{
H. I. Wahyuni, N. Suthama, I. Mangisah and T.A. Sarjana \\ Faculty of Animal Agriculture Diponegoro University \\ Tembalang Campus, Semarang 50275 - Indonesia \\ Corresponding E-mail: hannyindratwahyuni@yahoo.com
}

Received January 04, 2011; Accepted February 22, 2011

\begin{abstract}
The aim of study was to evaluate the effect of dietary vitamin E supplementation in Kedu and Cemani hens reraed in situ and given farmer-formulated diet on egg performances. A total of 120 female and 24 male birds were equally divided into two groups of Kedu and Cemani, with average body weight of $1890 \pm 216.79$ and $1830 \pm 396.23 \mathrm{~g}$, respectively. Basal ration was based on the diet formulated by the farmer (R1) consisting of corn $(30 \%)$, rice bran $(50 \%)$, protein concentrate $(15 \%)$, and premix $(5 \%)$.

Dietary treatments evaluated were R1 (without additional vitamin E), and the other three were the inclusion of DL $\alpha$-tocopheryl acetate into the R1 diet up to 2 (R2), 4 (R3) and 6 IU (R4). The experiment was arranged in a Randomized Block Design with 4 treatments, and 2 different groups of hen (Kedu and Cemani) were assigned as block. Parameters observed were feed consumption, hen day production, feed conversion ratio, egg quality, fertility, and hatchability. The result showed that vitamin E supplementation did not affect whatever parameters, except egg fertility. Egg hatchability between Kedu and Cemani hens was significantly different $(\mathrm{p}<0.05)$. Trend comparison test indicated significantly linear $(\mathrm{p}<0.05)$ for fertility and hatchability. In conclusion, vitamin E supplementation up to 6 IU increased linearly egg fertility and hatchability of about $5-8 \%$, and egg hatchability of Kedu hens was higher $(11 \%)$ than that of Cemani.
\end{abstract}

Keywords:egg fertility and hatchability, In situ, Kedu and Cemani hens, vitamin E

\section{INTRODUCTION}

Research conducted in the field of nutrition for local chicken in general, were almost focused on the evaluation of energy and protein requirement only during starting, growing and laying periods (Gultom et al., 1989; Widodo, 1989; Sukamto, 1997; Husmaini, 2005; Resnawati, 2005). Other researchs were also conducted on the utilization of non-conventional feedstuff in ration formulation for local chicken (Sudjarwo and Indarto, 1989; Usman et al., 2005; Suthama, 2005; Hermawan, 2007). However, information concerning dietary vitamin supplementation for breeder Kedu chicken at laying period was very limited and still in question.

Appropriate level of vitamin content in the ration for breeder chicken at laying period was important and was absolutely needed for embryonic development of hatching egg. Naber (1979) cited by NRC (1994) stated that vitamin requirement for breeder chicken of non local strain was higher than that of commercial laying chicken at the same period. In addition, genetic variation of non local chickens like broilers or layers was more uniform compared to local strain such as Kedu chicken. Therefore, it is necessary to study vitamin requirement of Kedu chicken for good quality of hatching egg production.

According to Leeson (2007), vitamin in eggs can be increased by increasing level of dietary vitamin supply. Among the four fat soluble vitamins, vitamin $\mathrm{A}$ is the most transferable vitamin from ration into the egg, followed by vitamin $\mathrm{D}$ and $\mathrm{E}$, while the lowest is vitamin $\mathrm{K}$ (Naber, 1993). Vitamin E plays a role in reproduction and embryonic development. Lack of vitamin $\mathrm{E}$ causes embryonic degeneration inside the egg (Church and Pond, 1998). Furthermore, Church and Pond (1998) explained that vitamin $\mathrm{E}$ deficiency in cock ration causes atrophy of the testes, furthermore it disrupts sperm production and quality.

National Research Council (1994) up to now, is the basic reference that commonly used to 
determine vitamin requirement for chicken, however, in reality vitamin requirement depends on the development of commercial feed specification (Leeson, 2007). In addition, Leeson (2007) also explained that the requirement of vitamin $\mathrm{A}, \mathrm{D}_{3}, \mathrm{E}$ and $\mathrm{K}$ for laying hens were higher by 5000, 3200, 45 and 2.5 IU, respectively, than those recommended by NRC (1994). The higher requirement also includes for all water soluble vitamins, except choline is lower than NRC (1994) recommendation. Therefore, it is suggested that vitamin requirement will be different or change according to the development and variation of genetic capacity of the chicken as well as the vitamins content of the rations.

Researchs on egg hatchability have been conducted previously by Sukamto (1997) in Kedu chicken fed diet with various levels of energy and protein, and Desmayati and Jannah (2005) in local chicken with dietary lysine supplementation. However, the two studies were carried out at the animal house of the laboratory, and both using individual battery pens, and mating system was conducted by artificial insemination. According to Sunarto et al. (2004) cited by Sulandari et al. (2007), type of floor affected body weight and carcass quality of Kedu chicken, thus, individual battery pens were suitable for meat producing Kedu chicken. Besides, mating system with artificial insemination is more difficult to be implemented and is also less adopted by the farmer of Kedu chicken. Therefore, in order to ensure environmental condition similar to that of the natural habitat of Kedu chicken, the present study of dietary vitamin E supplementation in Kedu hen was carried out in situ. The study was emphasized to evaluate the vitamin E requirement for hens between Kedu and Cemani (Jet-black chicken), reared naturally by the farmer, in relation to better performance and quality of eggs that would increase hatchability.

\section{MATERIALS AND METHODS}

Total number of 120 hens with different kind of hens, namely Kedu and Cemani (60 birds each) of 12-18 months of age at laying period with an average body weight of $1890 \pm 216.79$ and $1830 \pm 396.23 \mathrm{~g}$, respectively, were used in the experiment. Twenty four birds of cock of 20-24 months of age were also introduced to the hen population with the ratio of 5 females (hens) and 1 male (cock). Dietary treatment representing control group was the ration that formulated and usually used by the farmer which consisted of yellow corn $(30 \%)$, rice bran $(50 \%)$, concentrate $(15 \%)$ and premix $(5 \%)$. Nutritional contents of control ration (R1) were $11.78 \%$ crude protein, $6.30 \%$ crude fat, $18.12 \%$ crude fiber, $2.20 \% \mathrm{Ca}$, $0.84 \%$ P, 3063.95 kcal metabolizable energy $(\mathrm{ME}) / \mathrm{kg}$ and 0.13 IU vitamin E. Dietary treatments tested, namely farmer-formulated diet without supplementation of vitamin E (R1), and the other three were the inclusion of DL $\alpha$ tocopheryl acetate into the diet up to 2 IU (R2), 4 IU (R3) and 6 IU (R4).

The present experiment was conducted in a Randomized Block Design with 4 dietary treatments and 2 groups of different hen based on comb color (Kedu and Cemani) were assigned as block. The birds were kept in semi intensive pens as it was practiced by the farmer at Kedu village, where most of Kedu chickens were abundantly found. In order to measure feed consumption for the hens and cock separately, the pens were equipped with specific feeder. Pens were also equipped with drinking water containers, nest and nest shelter. Feeding trial was conducted for 3 months divided into 1 (one) month for feed adaptation and 2 months for collecting data. Eggs were collected everyday and hatched with hatching machine every 5 days of collection pools. The first hatching batch was conducted on the $\mathrm{d}-5$ of the second month of the feeding period. On the first 9 day of respective incubation period, the eggs were candled to distinguish fertile and unfertile eggs. Fertile eggs were indicated by the presence of embryonic development inside.

Parameters observed were feed consumption, hen day productions (HDP), feed conversion ratio (FCR), egg quality (weight of egg, egg-content, egg-shell and shell thickness) and fertility as well as hatchability. Fertility was measured by dividing number of eggs incubated with number of embryo-containing eggs, while hatchability was the value of the ratio between number of eggs hatched and number of fertile eggs. Data were subjected to analysis of variance according to a randomized block design as described previously, and it was continued with trend comparison test at the level of $5 \%$ probability.

\section{RESULTS AND DISCUSSION}

\section{Feed Consumption and Productivity}

The average of feed consumption, HDP and 
Table 1. Feed Consumption, Hen Day Production (HDP) and Feed Conversion Ratio (FCR) of Kedu and Cemani Hens Fed Farmer's Diet Formulation with Vitamin E Supplementation

\begin{tabular}{|c|c|c|c|c|c|c|}
\hline \multirow{2}{*}{ Parameters } & \multirow{2}{*}{ Kind of Hen } & \multicolumn{4}{|c|}{ Level of Vitamin E (IU) } & \multirow{2}{*}{ Average } \\
\hline & & 0.13 & 2 & 4 & 6 & \\
\hline \multicolumn{7}{|c|}{ Feed Consumption (g/hen/day) } \\
\hline & Kedu & 112.99 & 113.04 & 113.01 & 113.03 & 113.02 \\
\hline & Cemani & 111.68 & 113.24 & 112.96 & 111.45 & 112.33 \\
\hline & Average & 112.34 & 113.14 & 112.99 & 112.24 & 112.68 \\
\hline \multicolumn{7}{|l|}{$\operatorname{HDP}(\%)$} \\
\hline & Kedu & 30.43 & 34.43 & 33.87 & 32.31 & 32.76 \\
\hline & Cemani & 34.66 & 33.01 & 22.80 & 33.17 & 30.90 \\
\hline & Average & 32.55 & 33.72 & 28.34 & 32.74 & 31.83 \\
\hline \multicolumn{7}{|l|}{ FCR } \\
\hline & Kedu & 8.60 & 7.66 & 8.09 & 8.59 & 8.24 \\
\hline & Cemani & 8.12 & 8.91 & 12.35 & 8.24 & 9.41 \\
\hline & Average & 8.36 & 8.29 & 10.22 & 8.42 & 8.83 \\
\hline
\end{tabular}

FCR of Kedu and Cemani hens fed farmer's diet formulation with vitamin $\mathrm{E}$ supplementation reared in situ are presented in Table 1. Feed consumption ranged from 111.45 to 113.24 $\mathrm{g} / \mathrm{bird} /$ day, HDP ranged from 22.80 to $34.66 \%$, while the average of FCR was varied from 7.66 to 12.35. Feed consumption in the present study was about $20 \mathrm{~g} / \mathrm{bird} /$ day that was higher as compared to that of previous studies conducted by Sukamto (1997) and Setyaningrum et al. (2009). Since both studies were conducted in individual pens, the nutrient requirement supply was lower than those required by the hens in the present study because it was held in semi intensive pens. The energy requirement of the hens might be higher since they maintained in a semi intensive pen with wider space where the hens have much more opportunity to walk around and doing other activities. Thus, pen conditions bring about the increase in feed consumption.

The result of previous study (Sukamto, 1997; Setyaningrum et al. , 2009) when compared to the present study indicated higher HDP and lower feed conversion. Hen day production (HDP) and feed conversion of the present study was 10 and $50 \%$ lower, respectively. Improved dietary quality and management applied to the local chicken resulted in better productivity than those reared extensively or in situ, but it was still incomparable when reared commercially (Fairfull and Gowe, 2008).

Dietary supplementation of vitamin E did not significantly affect feed consumption, HDP and feed conversion in Kedu and Cemani hens reared in situ. This was due to the unchanged nutritional contents of the diet, except levels of vitamin E. All the farmer's formulated diet contained $11.78 \%$ crude protein and $3063.95 \mathrm{kcal} \mathrm{ME} / \mathrm{kg}$. Therefore, it was obvious that all hens consumed similar amount of feed since the energy-protein ratio was the same, and thus, resulted no different value on HDP and FCR.

\section{Egg Quality, Fertility and Hatchability}

Egg quality in term of average weight of egg, egg-content and egg-shell as well as eggshell thickness of Kedu and Cemani hens fed diet of farmer formulation with additional vitamin $\mathrm{E}$ reared in situ is presented in Table 2. Neither weight of egg, egg-content and egg-shell nor eggshell thickness was affected by dietary vitamin E supplementation. It was also observed that the kinds of hen did not significantly affect all parameters of egg quality. This means that egg produced by Kedu and Cemani hens had similar quality disregarding vitamin $\mathrm{E}$ supplementation. However, egg weight of the 2 different kinds of hens (Kedu and Cemani) were not in accordance 
Table 2. Egg Quality in Term of Weight of Egg, Egg-Content and Egg-Shell as well as Egg-Shell Thickness of Kedu and Cemani Hens Reared In situ Fed Ration of Farmer Formulation with Additional Vitamin E

\begin{tabular}{|c|c|c|c|c|c|c|}
\hline \multirow{2}{*}{ Parameters } & \multirow{2}{*}{ Kind of Hen } & \multicolumn{4}{|c|}{ Level of Vitamin E (IU) } & \multirow{2}{*}{ Average } \\
\hline & & 0.13 & 2 & 4 & 6 & \\
\hline \multicolumn{7}{|c|}{ Egg Weight (g/egg) } \\
\hline & Kedu & 43.68 & 42,35 & 42.90 & 40.43 & 42.34 \\
\hline & Cemani & 39.98 & 40.47 & 39.19 & 40.72 & 40.09 \\
\hline & Average & 41.82 & 41.41 & 41.05 & 40.56 & 41.22 \\
\hline \multicolumn{7}{|c|}{ Egg-Content Weight (g/egg) } \\
\hline & Kedu & 38.81 & 37.47 & 38.19 & 35.82 & 37.57 \\
\hline & Cemani & 35.34 & 35.44 & 34.99 & 35.74 & 35.38 \\
\hline & Average & 37.08 & 36.46 & 36.59 & 35.78 & 36.48 \\
\hline \multicolumn{7}{|c|}{ Egg-Shell Weight (g/egg) } \\
\hline & Kedu & 4.87 & 4.89 & 4.71 & 4.61 & 4.77 \\
\hline & Cemani & 4.64 & 5.02 & 4.20 & 4.98 & 4.71 \\
\hline & Average & 4.80 & 5.00 & 4.46 & 4.20 & 4.76 \\
\hline \multicolumn{7}{|c|}{ Egg-Shell Thickness (mm) } \\
\hline & Kedu & 0.36 & 0.36 & 0.34 & 0.35 & 0.35 \\
\hline & Cemani & 0.36 & 0.38 & 0.33 & 0.36 & 0.36 \\
\hline & Average & 0.36 & 0.37 & 0.34 & 0.36 & 0.36 \\
\hline
\end{tabular}

with the finding of Nataamijaya et al. (2006) that egg weight were significantly different among 3 local hens, namely Kampong, Sentul and Arab.

Table 3 indicates the average values of egg fertility and hatchability of Kedu and Cemani hens reared in situ and fed farmer-formulated ration with vitamin $\mathrm{E}$ supplementation. Egg fertility and hatchability values during 8 weeks observation in the present study was 5 and $19 \%$ lower, respectively, compared to those reported by Sulandari et al. (2007) within 20 weeks observation. Analysis of variance showed that vitamin $\mathrm{E}$ supplementation significantly affected egg fertility $(p<0.05)$ but not on hatchability. When it was continued to trend comparison test, the result indicated significantly linear $(p<0.05)$ for both. However, only egg hatchability showed significantly different $(p<0.05)$ due to the difference kinds of hen.

Dietary supplementation of vitamin E up to 6 $\mathrm{IU} / \mathrm{kg}$ ration in the present study was only able to increase linearly egg fertility and hatchability by around $7-9 \%$ and $2-8 \%$, respectively. This finding was almost similar to the study of Iriyanti et al. (2006) although the management was completely different as compared to the present study. The Kampong chicken were housed individually and produced fertile eggs through artificial insemination. The hens given vitamin $\mathrm{E}$ supplementation up to $30 \mathrm{mg} / \mathrm{kg}$ ration increased fertility of about $11 \%$ but not for hatchability (Iriyanti et al., 2006). Furthermore, higher vitamin E supplementation $(80 \mathrm{mg} / \mathrm{kg}$ ration) increased fertility but not hatchability in Taiwanese hens as reported by Lin et al. (2004). Even though the vitamin supplementation was higher compared to that in the present study, the increased egg fertility was more or less similar to those observed in the present study (7-10 vs. 7.7\%). The consistency phenomenon of the two studies can be confirmed and it is true that egg hatchability was not affected by vitamin $E$ supplementation.

Egg hatchability in Table 3 showed that around $15 \%$ of the embryo did not develope well up to the end of the hatching period. The two separated functions of vitamin E namely, supports 
Tabel 3. Eggs Fertility and Hatchability of Kedu and Cemani Hens Reared In situ Fed Farmer's Formulated Diet with Vitamin E Supplementation

\begin{tabular}{|c|c|c|c|c|c|c|}
\hline \multirow{2}{*}{ Parameters } & \multirow{2}{*}{ Kind of Hen } & \multicolumn{4}{|c|}{ Level of Vitamin E (IU) } & \multirow{2}{*}{ Average } \\
\hline & & 0.13 & 2 & 4 & 6 & \\
\hline \multicolumn{7}{|l|}{ Fertility $(\%)^{1)}$} \\
\hline & Kedu & 69.92 & 77.01 & 81.77 & 80.55 & 77.31 \\
\hline & Cemani & 69.79 & 75.37 & 76.21 & 77.20 & 74.79 \\
\hline & Average & $69.86^{\mathrm{c}}$ & $76.19^{\mathrm{b}}$ & $78.99^{\mathrm{a}}$ & $78.88^{\mathrm{a}}$ & 75.98 \\
\hline \multicolumn{7}{|l|}{ Hatchability $(\%)^{1)}$} \\
\hline & Kedu & 63.57 & 63.77 & 69.50 & 69.74 & $66.65^{\mathrm{a}}$ \\
\hline & Cemani & 50.12 & 55.44 & 54.73 & 60.71 & $55.25^{\mathrm{b}}$ \\
\hline & Average & 56.85 & 59.61 & 62.12 & 65.23 & 60.95 \\
\hline
\end{tabular}

the development of embryo and acts as an antioxidant, might be the cause of the problem of low egg hatchability. Although fat is the transporting carrier of vitamin $\mathrm{E}$ and is the main energy sources for the process of embryonic development, the beneficial effect of vitamin $E$ for eggs did not fully a hundred percent supports the development of embryos, but it should also partly be able to function as an antioxidant. According to Surai et al. (1999) the increasing of vitamin E concentration in chicken embryo's tissues, particularly in the brain cell, could reduce susceptibilities to peroxidation. The same mechanism is demonstrated by the study of Lin et al. (2005) that vitamin E supplementation of 120$160 \mathrm{mg} / \mathrm{kg}$ diet increased the capacity of its function as an antioxidant, which in turn reduced the stress level of the embryo against oxidative reactions. Therefore, for the future studies, it is necessary to consider the purpose of these two aspects in order to improve hatchability optimally through dietary addition of vitamin E. It is better to be considered that supplying vitamin $\mathrm{E}$ is not only for the reproduction needed but also as an antioxidant or its relationship with the action of other antioxidant vitamin such as vitamin A.

Low nutrients content of dietary treatment of the present study, except the ME value, in general might also contribute to the low egg hatchability. Protein content of the dietary treatment in the present study was $4-6 \%$ lower than that in the study of Sukamto (1997), this implies the poor quality of protein supply. Low egg hatchability was detrimental due to the multiple negative effects, namely, low quantity and poor quality of protein supply than the previous study. On the other hand, when ration with balance ratio of energy (2550, 2750 and $2950 \mathrm{kcal} / \mathrm{kg}$ ) and protein (13, 15 and 17\%) was given, did not affect egg hatchability (Sukamto, 1997). Embryonic development requires not only vitamin $\mathrm{E}$ but also the balance of other nutrients as well. Low embryonic development and egg hatchability were contrary to the previous finding as reported above. It can be argued that rearing system is greatly possible to bring about the different result. The difference of rearing system in relation to the effectiveness of nutrients utilization for egg hatchability is another problem that should be carefully considered. It have been discussed in the previous paragraph that the present study was conducted in semi-intensive model with an open space of pen allowing the hens to have chance doing exercise and walking around. For this condition, dietary nutrients content should be higher to cover the requirement as it was observed in this study.

Farmer's diet formulation was constantly given from starting period until egg laying without any change in the formula to adjust the nutrients requirement as the physiological age developed and the shifted of production purposes. 
Egg production capacity closely related to feeding pattern and nutrients utilization capability at the early period of age of the chickens. Kedu chicken reared in in situ fed diet of farmer formulation from starting until growing periods produced slow rate of protein turnover or low protein deposition as compared to nutritionally improved diet (Suthama, 2006). Feeding nutritionally unsatisfied diet causes chicken suffer nutritional stress and furthermore exerts the negative effect on productive capacity at laying period. Continuous nutritional stress brought about higher rate of protein degradation which was indicated by high excretion of intermediary amino acid called $\mathrm{N}^{\tau}$ methylhistidine (Suthama et al., 2010). Phenomenon of such condition resulted in low protein deposition or slow growth rate, whereas protein deposition at the starting - growing period is a precursor for the following period (laying period). It is obvious that poor nutritional condition of the diet, with low protein and high energy, as well as high fiber contents, given to the laying pullets from early period until egg production is less advantages for hatching egg production. On the other hand, feeding diet with higher nutritional contents, especially protein and vitamin $\mathrm{E}$, produces higher quality of hatching egg. Asli et al. (2007) reported that vitamin $\mathrm{E}$ supplementation could increase percentage of egg yolk from 26.6 to $28.3 \%$. Thus, it produced an increase in egg quality with higher hatching weight because egg yolk is a source of nutrient for the the embryonic development during hatching process and the first 3 days post-hatch .

The influence of the different kind of hens in the present study was significant only on hatchability parameter. Eggs hatchability of Kedu hens were higher than those of Cemani (Table 3). Cemani hens were obtained from the ancestor of both male and female of Kedu chicken, and producing offspring with the characteristic of Kedu Cemani chicken that was the main purposed of the relative mating. The specific characteristic in Cemani chicken is the jet-black appearance of the whole including the comb, skin, tongue and palate as well as the blood. It is well known to that Cemani chickens were economically very valuable commodity and high market demand. For this reason, farmers have been stimulated to breed their chickens by implementing relative mating continuously for years. Farmers do not aware and have no concern and consideration on the mating system that would actually bring about inbreeding depression. According to Harjosubroto
(1994) that such method of mating increased in inbreeding depression index by $10 \%$, and produced lower hatchability by about $1-4 \%$. Therefore, it is important to note that egg hatchability of Cemani was lower than that of Kedu as their ancestor due to the inbreeding mating model.

Lower egg hatchability or high embryonic mortality in Cemani chicken would be mainly related to the higher inbreeding index and possibly also to the bare-necked due to the relative mating from generation to generation. It is observed that about $15 \%$ of Cemani hens used in the present study indicated the bare-necked phenotype characteristic. According to Setianto et al. (2009) the bare-necked phenotypic was due to the $\mathrm{Na}$ gene, it could be either homozygote $(\mathrm{NaNa})$ or heterozygote locus (Nana). When the locus was heterozygote, the phenotypic of the neck was bald (Sidadolog, 1991 cited by Setianto et al., 2009). Therefore, it can be assumed that bare-neck gene might contribute to the low hatchability of Cemani eggs, since almost $20 \%$ of embryos were dead before hatching (74.79 vs. $55.25 \%$, Table 3). According to Fairfull and Gowe (2008), eggs from hens with Na gene have a high embryo mortality rate during hatching compared to that from hens without $\mathrm{Na}$ gene. Although gene characterization was not specified in the present study, it can be argued that more than $15 \%$ of Kedu hens carried heterozygote locus of $\mathrm{Na}$ gene (Nana). This assumption is supported by the finding of Setianto et al. (2009) that $19.7 \%$ of $\mathrm{Na}$ gene frequency was observed from some bare-neck cocks or hens randomly mated with normal-feathered of chicken or vice versa. It was also reported that the embryo mortality having bare-neck phenotype were higher than that of normal-feathered phenotype.

\section{CONCLUSION}

Supplementation of vitamin E up to the level of $6 \mathrm{IU}$ into the farmer-formulated diet increased egg fertility and hatchability linearly by around 5$8 \%$ in both Kedu and Cemani hens maintained in situ. However, egg hatchability of Cemani was $11 \%$ lower than that of Kedu hens.

\section{ACKNOWLEDGMENT}

The author is gratefully acknowledge and sincere thank due to the valuable financial support and contribution guaranteed by DP2M, 
Directorate of Higher Education, Ministry of National Education. The work for this manuscript was supported in part by the Grant-in-Aid no: 124A/H7.2/KP/2009 through Diponegoro University Budgeting Project (DIPA) no: 0160.0/023-04.2/XIII/2009.

\section{REFERENCES}

Asli, M.M., S.A. Hosseini, H. Lotfollahian, and F. Shariatmadari. 2007. Effect of probiotics yeast, vitamin $\mathrm{E}$ and vitamin $\mathrm{C}$ supplements on performance and immune response of laying hen during high environmental temperature. Int. J. Poult. Sci. 6(12):895-900.

Church, D.C. and W. G. Pond. 1998. Basic Animal Nutrition and Feeding. $4^{\text {th }}$ Ed. John Willey and Son, Singapore.

Desmayati Z. and I. R. Jannah. 2005. Suplementasi asam amino lisin dalam ransum basal ayam kampung petelur terhadap bobot telur, indeks telur, daya tunas dan daya tetas serta korelasinya. J. Indonesian Trop. Anim. Agric., Special Edition, Book 2, Page 39-46.

Fairfull, R.W. and R.S. Gowe. 2008. Breeding for resistance to heat stress. In: Poultry Production in Hot Climate. (Daghir, N.J., Ed). $2^{\text {nd }}$ Ed. CABI, London. Page. 13-29.

Gultom, D., D. Wiloeto, and Primasari. 1989. Protein dan energi rendah dalam ransum ayam buras periode bertelur. Proceedings, Seminar Unggas Lokal I. Semarang, September 28, 1989. Page 51-57.

Harjosubroto, W. 1994. Aplikasi Pemuliaan Ternak di Lapangan. PT. Grasindo, Jakarta.

Hermawan, D. 2007. Penggunaan Tepung Daun Pepaya (Carica papaya) dalam Ransum Ayam Arab Terhadap Produktivitas dan Anticacing. MS Thesis. Program Magister Ilmu Ternak, Fakultas Peternakan Universitas Diponegoro, Semarang.

Husmaini. 2005. Pengaruh pemberian beberapa level protein ransum terhadap penampilan $\mathrm{F} 1$ persilangan ayam arab dan kampung periode starter. J. Indonesian Trop. Anim. Agric, Special Edition, Book 2, Page 17-22.

lriyanti, N., Zuprizal, T. Yuwanta and S. Keman. 2007. The effect of vitamin $E$ supplementation in ration on fertility, hatchability and hatch weight of native chicken's eggs. Anim. Prod., Fakultas Peternakan Universitas Jendral Soedirman, Purwokerto. 9(1):36-9.
Leeson, S. 2007. Vitamin requirements: is there basis for re-evaluating dietary specifications. World Poult. Sci. J. 63(2): 255-266.

Lin, Y.F., S.J. Chang, and A.L. Hsu. 2004. Effects of supplemental vitamin $\mathrm{E}$ during the laying period on the reproductive performance of Taiwan native chickens. Br. Poult. Sci. 45(6):807- 814.

Lin, Y.F., H.L.Tsai, Y.C. Lee, and S.J. Chang. 2005. Maternal vitamin E supplementation affects the antioxidant capability and oxidative status of hatching chicks. J. Nutr. 135:2457-461.

Naber, E. C. 1993. Modifying vitamin composition of eggs: A review. J. Appl. Poult. Res. 2:385-393.

Nataamijaya, A.G., Arnesto and S.N. Jarmani, 2006. Reproduction performance of female local chickens breeds under vitamin $\mathrm{E}$ supplementation. Anim. Prod. (Fakultas Peternakan Universitas Jenderal Soedirman, Purwokerto). 8(2):78-82.

National Research Council. 1994. Nutrient Requirement of Poultry. $9^{\text {th }}$ Ed. National Academic Press, Washington.

Resnawati, H. 2005. Kebutuhan energi metabolis dalam ransum ayam silang yang dipelihara secara intensif. J. Indonesian Trop. Anim. Agric, Special Edition. Book 2, Page 23-26.

Setianto, J., Warnoto, and T. Triadi. 2009. Estimation of $\mathrm{Na}$ gene frequency on native chicken population and its effect on hatchability performance. J. Indonesian Trop. Anim. Agric. 34:284-288.

Setyaningrum, S., .H.I. Wahyuni and B. Sukamto. 2009. Pemanfaatan Kalsium Kapur dan Kulit Kerang untuk Pembentukan Cangkang dan Mobilisasi Kalsium Tulang pada Ayam Kedu. Proceedings, National Seminar on "Teknologi Peternakan dan Veteriner", Bogor, August 4-5, 2009. Page 674-681.

Sudjarwo, E and P. Indarto. 1989. Pengaruh penggunaan berbagai macam bahan litter terhadap pertambahan bobot badan dan konsumsi pakan ayam kampung umur 8-12 minggu. Proceedings, Seminar Unggas Lokal I, Semarang, September 28, 1989. Page 6871.

Sukamto, B. 1997. Kebutuhan Energi dan Protein Berdasarkan Efisiensi Penggunaan Protein dengan Manifestasinya terhadap Performan Produksi Ayam Kedu. PhD Thesis. Program Pasca Sarjana Universitas Padjadjaran, Bandung. 
Sulandari, S., M.S.A. Zein, S. Paryanti, T. Sartika, M. Astuti, T. Widjastuti, E. Sujana, S. Darana, I. Setiawan, and D. Garnida. 2007. Sumberdaya genetik ayam lokal Indonesia. In: Keanekaragaman Sumber Daya Hayati Ayam Lokal Indonesia: Manfaat dan Potensi. (Diwyanto, K and S. N. Prijono, Eds). $1^{\text {st }}$ Ed. LIPI Press, Jakarta. Page 43-104.

Surai, P.F., R.C. Noble, and B.K. Speke. 1999. Relationship between vitamin E content and susceptibility to lipid peroxidation in tissues of the newly hatched chick. Br. Poult. Sci. 40:406-410.

Suthama, N. 2005. Respon produksi ayam kampung petelur terhadap ransum memakai dedak padi fermentasi dengan suplementasi sumber mineral. J. Indonesian Trop. Anim. Agric, Special Ed., Book 2, Page 116-121.
Suthama, N. 2006. Kajian aspek "protein turnover" tubuh pada ayam Kedu periode pertumbuhan. Media Peternakan 29(2):47-53. Suthama, N., H.I. Wahyuni, and I. Mangisah. 2010. Laju pertumbuhan berdasarkan degradasi protein tubuh pada ayam Kedu dipelihara ex situ. Proceedings, Seminar Unggas Lokal IV, Semarang, October 7, 2010. Page 138-146.

Usman, Atekan and S. Tirayoh. 2005. Potensi dan manfaat limbah buah merah sebagai pakan ayam buras petelur. J. Indonesian Trop. Anim. Agric., Special Ed., Book 2, Page 3238.

Widodo, E. 1989. Pengaruh berbagai tingkat protein ransum terhadap pertumbuhan ayam buras. Proceedings, Seminar Unggas Lokal I, Semarang, September 28, 1989. Page 48-50. 